\title{
Research Square \\ Public Perception and Investment Preference for the Companies Contributing to CSR
}

Pankaj Sharma ( $D$ sharmapankaj12011996@gmail.com )

Shri K K Shastri Government Commerce College https://orcid.org/0000-0002-0848-8704

Pragnesh Dalwadi ( $\nabla$ pragnesh1606@gmail.com )

S D School of Commerce, Gujarat University

\section{Research Article}

Keywords: Corporate Social Responsibility, Awareness, Public Perception, Investment Preference, Public Issue

Posted Date: November 16th, 2021

DOI: https://doi.org/10.21203/rs.3.rs-1078246/v1

License: (1) This work is licensed under a Creative Commons Attribution 4.0 International License. Read Full License 
Title: Public Perception and Investment Preference for the Companies Contributing to CSR

\section{Author}

Pragnesh B. Dalwadi

Senior Research Fellow

S D School of Commerce, Gujarat University

Navrangpura, Ahmedabad

E-Mail ID: pragnesh1606@gmail.com

Mobile Number: 9727969971

\section{Co-Author}

Pankaj Sharma

Assistant Professor (GES-II)

Shri K. K. Shastri Government Commerce College

Khokhra Road, Maninagar, Ahmedabad - 380008

Scopus ID: $\underline{57214455529}$

ORCID: 0000-0002-0848-8704

Google Scholar ID: Pankaj Parmeshwar Sharma

Academia.edu: pankajsharma

Research Gate ID: Pankaj-Sharma-145

E-Mail ID: pankajkms731@gmail.com

E-Mail ID: sharmapankaj12011996@gmail.com

Mobile Number: 9662971417 


\title{
Public Perception and Investment Preference for the Companies Contributing to CSR
}

\begin{abstract}
The corporate social responsibility concentrates on corporate goals to "give back to the society" or be converted into "agents of positive social change". Therefore it is important to understand the people's perception for corporate social responsibility and their investment preference in companies contributing to CSR. To know people's perception of CSR the descriptive research design has been used and the data has been collected from 285 individuals of Ahmedabad city through structured questionnaire using random sampling method in the month of January and February 2021. The collected data has been tabulated and analyzed using frequency count, percentage, chi-square test, and multiple-regression. This study found that eighty five percent of the respondents are aware of CSR. The respondents believe that CCCSR are responsible companies and therefor people spread positive word-of-mouth for these companies but people are not ready to pay higher price for the products and services offered by these companies. Therefor companies should invest in CSR and this investment gives handsome financial and non-financial returns in the form of improved company reputation, customer satisfaction, trustworthiness, customer loyalty, investors' confidence etc.
\end{abstract}

Keywords: Corporate Social Responsibility, Awareness, Public Perception, Investment Preference, Public Issue

\section{Introduction}

The money considered as a life blood of any business as it is the most necessitous part of all the functions of a business (Pankaj Sharma, 2018). However, the emerging wave in corporate social responsibility signals that businesses are attempting to do better for the environment in addition to making profits. Companies make corporate social commitments as they devote time and energy to these social, environmental, and economic causes. Societal initiatives concentrate on corporate goals to "give back to the society" or be converted into "agents of positive social change" (Dalwadi \& Sharma, 2019). Corporate social responsibility is described as where these community programmes are made obligatory for corporations by statute. The relationship between businesses and society has slowly evolved from a hard-core enterprise to a philanthropic relationship. (Shergill, 2012). Corporate social responsibility is described as a holistic collection of policies, practices, and making programs that are incorporated into corporate activities, supply chains, and decision- processes within the enterprise, everywhere it does business, and provides accountability for current and past activity as well as potential impacts. (Shergill, 2012). Employees' perceptions of their company's social responsibility behaviors are more important than organizational reality in determining organizational identification (Glavas \& Godwin, 2013). Consumers' social issues have been addressed by CSR campaigns, such as providing goods with socially beneficial qualities or producing products in a socially responsible way. (McWilliams \& Siegel, 2001). There are three players in cause-related marketing. When a customer enters in a revenueproducing activity with the corporation, the company announces that it will contribute a certain amount of money to a charitable cause. This indicates the interconnection of company, consumer, and charitable cause affecting parties (Dean, 2003). This responsibility necessitates companies contributing financial and human resources to the community, as well as assisting in the improvement of the community's quality of life. Its resulting benefits can be (Dean, 2003); 
$>$ Creation of goodwill with the community,

$>$ Differentiation of the corporate image and its brands from competitors

$>$ Increase in employee and channel member morale

$>$ Use as a shield against public criticism in times of crisis

$>$ Winning over skeptical public officials

$>$ Increased revenues and profits

The new information is interpreted in light of the observer's previous experiences, beliefs, and feelings (Sherif and Hovland 1961) and thus the social responsibility is viewed by corporations as an investment that improves the long-term performance of the organization (Varadarajan and Menon 1988).

According to the contrast effect, firms that make similar charitable contributions can be judged differently by customers based on the firm's reputation for social responsibility. The announcement of a corporate donation by an irresponsible company, for example, is likely to result in a contrast effect. The irresponsible firm will be described in such a way that making a charitable donation (of either type) would be out of character for the firm. On the other hand, information that a scrupulous firm is making a charitable donation would not be surprising, and no contrast effect is expected.

Attributions are the result of a cognitive process by which people assign an underlying cause or explanation to an observed event (Kelly 1973; Kelly and Michela 1980). That is, individuals will try to develop a commonsense explanation of why actions have occurred and make causal inferences. It is assumed that people make attributions to achieve a greater level of understanding (and thus control) over their lives and environment. Consumers are known to make attributions about why a product failed, why they switched brands, why a celebrity agreed to appear in an endorsement, and why a firm's employees are on strike (Folkes 1988).

Social responsibility is important in determining corporate effectiveness (Lachman and Wolfe, 1997). Most observers expect that "good companies"' (that is, companies that have a reputation for being socially responsible) will attract consumers to their products, while "bad companies" (that is, companies that disregard their social obligations) will be punished by the consumers - for example, through boycotts (Castaldo et al., 2009). Consumers are interested in the social behavior of firms, and this behavior influences their purchasing decisions (Castaldo et al., 2009).

A.B. Carroll, one of the pioneers of CSR, defines it as: The total corporate social responsibility of business entails the simultaneous fulfillment of the firm's economic, legal, ethical and philanthropic responsibilities. Stated in more pragmatic and managerial terms, the CSR firm should strive to make a profit, obey the law, be ethical, and be a good corporate citizen (Carroll, 1991). Carroll proposes a model that divides CSR into four components. The economic aspect requires companies to perform well economically and meet consumer demands. The legal aspect requires them to carry out their economic mission in accordance with the law. The ethical dimension requires companies to follow society's moral laws. The final part is charitable and philanthropic in nature (Carroll, 1979).

The CSR literature proposes that the consumer perceives an additional benefit in the purchase of products that are associated to CSR (Strahilevitz, 1999; Smith, 1996). CSR is meaningless in day-to-day operations if management's prime concern is not with continuing the long-term health of the enterprise (Ingham, 2006). 
The corporations are expected to engage in the improvement of their employees' quality of life, as well as the well-being of employees' families, local communities, and the overxall society (Zheng, 2010). CSR can attract investors and customers, as well as maintain a positive interaction with the government (Zheng, 2010). A growing number of studies have been done regarding the benefits of CSR. However, most are concerned with the financial and customer perspective (Zheng, 2010). Some corporations invest in CSR because it is the "right thing to do"; it is aligned with the beliefs of the management and corporate culture; it is part of the strategic plan; it is a current thing to do as most of the other organizations do it; or management expects to be rewarded for it by the market (Dilling, 2011). About seventy percent of related studies showed a positive and statistically relevant relationship between CSR and financial performance (Dilling, 2010). To make people aware of corporate social responsibility, these companies should advertise their socially responsible behavior through different media including social media platform that offers and entertainment and practical use of content (Sharma \& Chakravarthy, 2020).

More specifically, the study will search to answer the following questions:

1) How many people are aware of corporate social responsibility?

2) How the reputation, customer satisfaction, trust, and loyalty for the companies contributing to CSR perceived by people?

3) Do customers are willing to pay high price for the products or services of companies contributing to CSR?

4) Do people prefer to invest in companies contributing to CSR? 
Important Literature Review

\begin{tabular}{|c|c|c|c|c|}
\hline Author(s) & Year & Sample Unit & Sample Size & Results \\
\hline Elias & 2004 & $\begin{array}{c}\text { Customers } \\
\text { (Business Students) } \\
\end{array}$ & 466 & $\begin{array}{l}\text { CSR is important for profitability and long term success } \\
\text { of corporates. }\end{array}$ \\
\hline Lee \& Heo & 2009 & Hotels and Restaurants & $32 \& 43$ & $\begin{array}{l}\text { CSR activities affect the firm value but customer } \\
\text { satisfaction does not mediate the relationship. }\end{array}$ \\
\hline Castaldo et al. & 2009 & $\begin{array}{l}\text { Customers } \\
\text { (Retail) }\end{array}$ & 400 & $\begin{array}{l}\text { Socially oriented companies can successfully leverage } \\
\text { their reputation to market products with high symbolic } \\
\text { values and customer buys such products. }\end{array}$ \\
\hline Ferreira et al. & 2010 & $\begin{array}{l}\text { Customers } \\
\text { (Experiment) }\end{array}$ & 172 & $\begin{array}{l}\text { Customers perceive greater value and benefit in socially } \\
\text { responsible company and willing to pay ten percent more } \\
\text { for its product. }\end{array}$ \\
\hline Arli \& Lasmono & 2010 & $\begin{array}{c}\text { Customers } \\
\text { (students from developing nations) }\end{array}$ & 443 & $\begin{array}{l}\text { Customers would spend their money to buy the most } \\
\text { affordable products, despite a company's high or low } \\
\text { involvement in CSR activities. }\end{array}$ \\
\hline Zheng & 2010 & Employees & 331 & $\begin{array}{l}\text { Employees' perception of CSR influences their } \\
\text { subsequent work outcomes. }\end{array}$ \\
\hline Wong et al. & 2010 & $\begin{array}{c}\text { Customers } \\
\text { (Business Students) }\end{array}$ & 317 & $\begin{array}{l}\text { Americans and Indians attached more importance to the } \\
\text { non-economic aspects of CSR compared to Chinese. }\end{array}$ \\
\hline Dilling & 2011 & $\begin{array}{c}\text { Companies and their } \\
\text { stakeholders }\end{array}$ & 50 & $\begin{array}{l}\text { CSR perception of stakeholders is significantly } \\
\text { influenced by age of the corporation, community } \\
\text { involvement, and cultural diversity. }\end{array}$ \\
\hline Shergill & 2012 & Consumers & 225 & $\begin{array}{l}\text { Consumers have higher expectations as compared to } \\
\text { what they perceive, regarding the social responsibility of } \\
\text { the companies. }\end{array}$ \\
\hline Bae \& Kim & 2013 & $\begin{array}{c}\text { Consumers } \\
\text { (University Students) }\end{array}$ & 840 & $\begin{array}{l}\text { The cultural characteristics influences the importance } \\
\text { attributed to CSR activities }\end{array}$ \\
\hline Kaifi et al. & 2014 & $\begin{array}{c}\text { Consumers } \\
\text { (Millennial) }\end{array}$ & 180 & $\begin{array}{l}\text { The female students, students born in a high-context } \\
\text { culture and millennial have a higher commitment to } \\
\text { corporate social responsibility. }\end{array}$ \\
\hline
\end{tabular}




\begin{tabular}{|c|c|c|c|c|}
\hline \multirow[t]{2}{*}{ Wu \& Wang } & \multirow[t]{2}{*}{2014} & Generation $-\mathrm{X}$ & \multirow[t]{2}{*}{624} & $\begin{array}{l}\text { In the X-generation, the influence of environmental CSR } \\
\text { on experiential brand image, and the influence of brand } \\
\text { attitude on future buying willingness, is more significant } \\
\text { than with the Y-generation. }\end{array}$ \\
\hline & & Generation - Y & & $\begin{array}{l}\text { In the Y-generation, the impact of community CSR on } \\
\text { experiential brand image, and the impact of symbolic } \\
\text { brand awareness on brand attitude are more significant } \\
\text { than with the X-generation. }\end{array}$ \\
\hline Zhu et al. & 2014 & Employees & 438 & $\begin{array}{l}\text { Solely providing money-related welfare and improving } \\
\text { the working environment can be detrimental to employee } \\
\text { loyalty, but by increasing employee satisfaction of } \\
\text { personal treatment, companies can mitigate such a side- } \\
\text { effect. }\end{array}$ \\
\hline Vahdati et al. & 2015 & Households & 200 & $\begin{array}{l}\text { Customers' positive attitude to corporate social } \\
\text { responsibility has positive and direct impact on buying } \\
\text { behavior. }\end{array}$ \\
\hline Huang & 2016 & Employees & 287 & $\begin{array}{l}\text { 1. Employees' perception of CSR has a significant } \\
\text { positive effect on their intention to participate in } \\
\text { corporate volunteer; } \\
\text { 2. Employees' perception of CSR has a significant } \\
\text { positive effect on organizational commitment; } \\
\text { 3. Employees' intention of participating in corporate } \\
\text { volunteer has a significant positive effect on } \\
\text { organizational commitment. }\end{array}$ \\
\hline Nguyen \& Truong & 2016 & Consumers & $\begin{array}{l}\text { Conceptual } \\
\text { Framework }\end{array}$ & $\begin{array}{l}\text { In general, research on CSR is fragmented with four } \\
\text { distinguished approaches namely instrumental, political, } \\
\text { integrative and ethical theories. }\end{array}$ \\
\hline Rivera et al. & 2016 & $\begin{array}{c}\text { Companies } \\
\text { (US) }\end{array}$ & 65 & $\begin{array}{l}\text { Positive direct relationship between CSR and customer } \\
\text { satisfaction with CSR training and environmental } \\
\text { initiatives, but a negative direct relationship between } \\
\text { CSR corporate communication initiatives and customer } \\
\text { satisfaction. }\end{array}$ \\
\hline
\end{tabular}




\begin{tabular}{|c|c|c|c|c|}
\hline & & Online Survey & 351 & $\begin{array}{l}\text { Direct or indirect positive relationship between CSR and } \\
\text { customer satisfaction through brand attitudes. }\end{array}$ \\
\hline Famiyeh et al. & 2016 & Firms and Customers & 165 & $\begin{array}{l}\text { Corporate social responsibility initiatives by firms } \\
\text { enhance their reputation as well as their overall } \\
\text { performance in terms of profitability, sales growth, and } \\
\text { market share. }\end{array}$ \\
\hline Agudo-Valiente & 2017 & Firms & 416 & $\begin{array}{l}\text { Subjective CSR Drivers: integration of ethics and } \\
\text { sustainable development principles. } \\
\text { Objective CSR Drivers: stakeholder pressure, } \\
\text { institutional framework and reputation management. } \\
\text { Subjective CSR Barriers: public relations, charitable } \\
\text { behavior and philanthropy. } \\
\text { Objective CSR Barriers: availability of financial, time- } \\
\text { related and human resources. }\end{array}$ \\
\hline Rim \& Dong & 2018 & General Public & 1121 & $\begin{array}{l}\text { U.A.E.: the public tend to put more emphasis on } \\
\text { economic and philanthropic duties for business, whereas } \\
\text { in a more suspicious society like South Korea: public } \\
\text { consider legal and ethical responsibility to be important. }\end{array}$ \\
\hline Abraham et al. & 2018 & $\begin{array}{l}\text { General Public } \\
\text { (Interview) }\end{array}$ & 20 & $\begin{array}{l}\text { There was a gap between the perception of the } \\
\text { community members about company's CSR and the } \\
\text { observed CSR activities of company. }\end{array}$ \\
\hline Farrukh et al. & 2019 & Employees & 470 & $\begin{array}{l}\text { 1. Significant positive impact of CSR perception on } \\
\text { Employees Engagement } \\
\text { 2. Stronger relationship between CSR and women than } \\
\text { men }\end{array}$ \\
\hline Diers-Lawson et al. & 2020 & $\begin{array}{l}\text { Customers \& Practitioners } \\
\text { (FGD) }\end{array}$ & 39 & $\begin{array}{l}\text { Consumer efficacy to influence an organization and } \\
\text { localized CSR emerge as critical determinants for } \\
\text { evaluations of CSR as authentic. Further, these data also } \\
\text { suggest practitioners may not understand consumer } \\
\text { motivations and attitudes about CSR. }\end{array}$ \\
\hline
\end{tabular}




\begin{tabular}{|c|c|c|c|l|}
\hline Ramasamy et al. & 2020 & Consumers & 479 & $\begin{array}{l}\text { Human values such as self enhancement and openness to } \\
\text { change have a significant influence on consumer CSR } \\
\text { perception with Consumer skepticism as a moderator in } \\
\text { the relationship. }\end{array}$ \\
\hline
\end{tabular}

\begin{tabular}{|c|c|c|c|c|}
\hline \multicolumn{2}{|c|}{ Factors Affecting CSR Perception } & \multicolumn{3}{|c|}{ CSR Perception Affects Factors } \\
\hline Corporate & Customers & Employees & Consumers & Corporate \\
\hline $\begin{array}{l}\text { Age of the corporation } \\
\text { (Dilling, 2011) }\end{array}$ & $\begin{array}{l}\text { Customers Cultural } \\
\text { Characteristics } \\
\text { (Bae \& Kim, 2013) }\end{array}$ & $\begin{array}{l}\text { Employees work Outcomes } \\
\text { (Zheng, 2010) }\end{array}$ & $\begin{array}{l}\text { Reputation of Product } \\
\text { (Castaldo et al., 2009) }\end{array}$ & $\begin{array}{l}\text { Profitability } \\
\text { (Elias, 2004) \& } \\
\text { (Famiyeh et al., 2016) }\end{array}$ \\
\hline $\begin{array}{l}\text { Community involvement in } \\
\text { Activities } \\
\text { (Dilling, 2011) }\end{array}$ & $\begin{array}{l}\text { Human } \quad \text { Values } \\
\text { (Ramasamy et al., 2020) }\end{array}$ & $\begin{array}{l}\text { Employee Loyalty } \\
\text { (Zhu et al., 2014) }\end{array}$ & $\begin{array}{l}\text { Customers Perceived Value } \\
\text { (Ferreira et al., 2010) }\end{array}$ & $\begin{array}{l}\text { Long term } \text { Success } \\
(\text { Elias, 2004) }\end{array}$ \\
\hline \multirow{6}{*}{$\begin{array}{l}\text { Cultural Diversity in } \\
\text { Activities } \\
\text { (Dilling, 2011) }\end{array}$} & $\begin{array}{l}\text { Self Enhancement } \\
\text { (Ramasamy et al., 2020) }\end{array}$ & $\begin{array}{l}\text { Employee Satisfaction (Zhu } \\
\text { et al., 2014) }\end{array}$ & $\begin{array}{l}\text { Customers Expectation } \\
\text { (Shergill, 2012) }\end{array}$ & $\begin{array}{l}\text { Firm Value } \\
\text { (Lee \& Heo, 2009) }\end{array}$ \\
\hline & $\begin{array}{l}\text { Openness to Change } \\
\text { (Ramasamy et al., 2020) }\end{array}$ & $\begin{array}{l}\text { Employees Participation } \\
\text { (Huang, 2016) }\end{array}$ & $\begin{array}{l}\text { Brand Image } \\
\text { (Wu \& Wang, 2014) }\end{array}$ & $\begin{array}{l}\text { Reputation of Product } \\
\text { (Castaldo et al., 2009) }\end{array}$ \\
\hline & & $\begin{array}{l}\text { Organisational Commitment } \\
\text { (Huang, 2016) }\end{array}$ & $\begin{array}{l}\text { Future buying willingness[I] } \\
\text { (Wu \& Wang, 2014) }\end{array}$ & $\begin{array}{l}\text { Brand Image } \\
\text { (Wu \& Wang, 2014) }\end{array}$ \\
\hline & & $\begin{array}{l}\text { Employee Engagement } \\
\text { (Farrukh et al., 2019) }\end{array}$ & $\begin{array}{l}\text { Customers Buying } \\
\text { behaviour } \\
\text { (Vahdati et al., 2015) }\end{array}$ & $\begin{array}{l}\text { Corporate Reputation } \\
\text { (Famiyeh et al., 2016) }\end{array}$ \\
\hline & & & $\begin{array}{l}\text { Customer satisfaction (D/I) } \\
\text { (Rivera et al., 2016) }\end{array}$ & $\begin{array}{l}\text { Sales Growth } \\
\text { (Famiyeh et al., 2016) }\end{array}$ \\
\hline & & & & $\begin{array}{l}\text { Market Share } \\
\text { (Famiyeh et al., 2016) }\end{array}$ \\
\hline
\end{tabular}




\section{Methodology}

The main objective of the study is to know the people's perception for CSR and investment preference in companies contributing to CSR. To meet this objective the relevant literature has been studied and identified that numerous studies has been conducted on CSR and its financial aspects, customer perception, employees perception, and public's perception for CSR. However, very few studies have been conducted on identifying the people's investment preference in companies contributing to CSR. To meet this objective descriptive research design has been used and the data has been collected from 285 individuals of Ahmedabad city through structured questionnaire using random sampling method in the month of January and February 2021. The collected data has been tabulated and analyzed using frequency count, percentage, chi-square test, and multiple-regression.

\section{Data Analysis}

Table 1

Demographics of Respondents

\begin{tabular}{|c|c|c|c|}
\hline Variable & Category & Frequency & $\%$ \\
\hline \multicolumn{4}{|l|}{ Gender } \\
\hline & Male & 72 & 25.3 \\
\hline & Female & 213 & 74.7 \\
\hline \multicolumn{4}{|l|}{ Age } \\
\hline & $19-25$ & 246 & 86.3 \\
\hline & $26-45$ & 39 & 13.7 \\
\hline \multicolumn{4}{|c|}{ Educational Qualification } \\
\hline & Under Graduate & 12 & 4.2 \\
\hline & Graduate & 96 & 33.7 \\
\hline & Post Graduate & 153 & 53.7 \\
\hline & Others & 24 & 8.4 \\
\hline \multicolumn{4}{|l|}{ Occupation } \\
\hline & Academicians & 90 & 31.6 \\
\hline & $\begin{array}{l}\text { Employee - } \\
\text { Private/Public }\end{array}$ & 27 & 9.5 \\
\hline & Self Employed & 24 & 8.4 \\
\hline & Home Maker & 48 & 16.8 \\
\hline & Searching for Job & 96 & 33.7 \\
\hline \multicolumn{4}{|c|}{ Number of Family member } \\
\hline & upto 4 & 150 & 52.6 \\
\hline & 5 or more & 135 & 47.4 \\
\hline \multicolumn{4}{|c|}{ Monthly Family Income } \\
\hline & Below 25,000 & 84 & 29.5 \\
\hline & $25,000-50,000$ & 90 & 31.6 \\
\hline & $50,001-75,000$ & 42 & 14.7 \\
\hline & Above 75,000 & 69 & 24.2 \\
\hline \multicolumn{4}{|c|}{$\begin{array}{l}\text { Do you Know about Corporate } \\
\text { Social Responsibility? }\end{array}$} \\
\hline & Yes & 243 & 85.3 \\
\hline & No & 42 & 14.7 \\
\hline & Total & 285 & 100 \\
\hline
\end{tabular}


Corporate social responsibility is hardly known by German consumers (Hartmann et al, 2013), while in Hindustan more than $85 \%$ peoples are aware of corporate social responsibility.

Table 2

Chi-square test between demographics and awareness

\begin{tabular}{lcc}
\hline Awareness & Pearson Chi-Square & Asymp. Sig. (2-sided) \\
\hline Gender & 2.855 & 0.0911 \\
Educational Qualifications & 2.170 & 0.5379 \\
Occupation & 4.289 & 0.3683 \\
Monthly Family Income & 1.440 & 0.6962 \\
Number of family Member & 0.046 & 0.8309 \\
Age & 2.603 & 0.1067 \\
\hline
\end{tabular}

The present study indicates that there is no significant association between awareness of corporate social responsibility and demographics of respondents; contradicting to (Khurshid et al, 2013) and (Sardianou et al, 2017) awareness of corporate social responsibility among respondents was differentiated with demographics.

Table 3

Public Awareness of CCCSR

\begin{tabular}{ll}
\hline \multicolumn{2}{c}{ Public Awareness of Companies Contributing to CSR } \\
\hline Don't Remember any company & $11.10 \%$ \\
Remember the name of companies & $88.90 \%$ \\
\hline
\end{tabular}

The data indicates that more than $88 \%$ of people from those who are aware of corporate social responsibility (CSR) remember the companies contributing to corporate social responsibility (CCCSR). This may result in a direct or indirect benefit in a financial or nonfinancial way to the companies contributing to CSR from the public and customers. The nonfinancial benefits can be customer loyalty, company reputation, customers' trust for the company, customer satisfaction, and positive word-of-mouth. In spite of non-financial benefits, some financial benefits can be availed to the company in the form of increased customers, cost savings, easier access to capital, etc. 
Table 4

Public Perception of Companies Contributing to CSR

\begin{tabular}{lccccc}
\hline Public Perception of CSR & Very Low & Low & No Impact & High & Very High \\
\hline Reputation of company & $3.70 \%$ & $3.70 \%$ & $16.05 \%$ & $60.49 \%$ & $16.05 \%$ \\
Customer Satisfaction & $1.23 \%$ & $8.64 \%$ & $29.63 \%$ & $44.44 \%$ & $16.05 \%$ \\
Trust for company & $2.47 \%$ & $11.11 \%$ & $13.58 \%$ & $53.09 \%$ & $19.75 \%$ \\
Behavioural Loyal to company & $2.47 \%$ & $14.81 \%$ & $14.81 \%$ & $43.21 \%$ & $24.69 \%$ \\
\hline
\end{tabular}

As we already discussed that enormous number of peoples remember the companies contributing to CSR. Further collected survey data indicates that more than $76 \%$ of respondents believe that CSR activities will enhance the reputation of companies. More than $60 \%$ of respondents are of the opinion that customers are satisfied with the products or services of CCCSR. The corporate activities for social and environmental wellbeing will enhance the trust for the company in more than $72 \%$ of respondents. More than $67 \%$ of respondents are of the opinion that they will remain loyal to the CCCSR. These results indicate the positive perception and mind set of customers about CCCSR and it will benefit these companies directly or indirectly in short term and long term future.

Table 5

Public Perception of CSR

\begin{tabular}{lccccc}
\hline Public Perception of CSR & SD & D & N & A & SA \\
\hline $\begin{array}{l}\text { I would prefer products/services offered by } \\
\text { Companies contributing to CSR }\end{array}$ & $14.81 \%$ & $6.17 \%$ & $9.88 \%$ & $46.91 \%$ & $22.22 \%$ \\
$\begin{array}{l}\text { Actions of Companies are directed towards } \\
\text { improving environment and social wellbeing }\end{array}$ & $13.58 \%$ & $6.17 \%$ & $11.11 \%$ & $43.21 \%$ & $25.93 \%$ \\
$\begin{array}{l}\text { I would prefer to invest in companies contributing } \\
\text { to CSR }\end{array}$ & $13.58 \%$ & $7.41 \%$ & $9.88 \%$ & $50.62 \%$ & $18.52 \%$ \\
$\begin{array}{l}\text { Companies contributing to CSR are responsible } \\
\text { companies }\end{array}$ & $14.81 \%$ & $8.64 \%$ & $8.64 \%$ & $51.85 \%$ & $16.05 \%$ \\
$\begin{array}{l}\text { I encourage others to buy products/services of } \\
\text { companies contributing to CSR }\end{array}$ & $12.35 \%$ & $13.58 \%$ & $13.58 \%$ & $48.15 \%$ & $12.35 \%$ \\
$\begin{array}{l}\text { I have willingness to pay High price for } \\
\text { products/services of companies contributing to CSR }\end{array}$ & $14.81 \%$ & $32.10 \%$ & $24.69 \%$ & $23.46 \%$ & $4.94 \%$ \\
\hline
\end{tabular}

There were several statements presented in before respondents to give their agreement or disagreement in a five point likert scale. The data presents that more than $69 \%$ of respondents would prefer the products or services offered by CCCSR. This indicates that customers have trust on CCCSR and they become loyal and supportive to these companies. The rest of the respondents may prefer the products or services after evaluating them on some other aspects too. More than $69 \%$ of respondents are of positive opinion towards CCCSR and they think that the actions of these companies are directed towards improving social and environmental wellbeing. More than $69 \%$ of respondents would prefer to invest in the CCCSR that means companies will get the benefit of easier access to capital. More than $67 \%$ of respondents believe that CCCSR are responsible companies. More than $60 \%$ of respondents will encourage others to buy products or services offered by CCCSR that indicates that peoples who are aware of CSR activities of company will spread positive word-of-mount and this will 
benefit company. However, there is a diversified opinion from respondents on account of spending higher price for buying the products or services of CCCSR and if we look into data more carefully it shows that majority of respondents are not willing to pay higher price for it.

Table 6

Priority Areas for Corporate Social Responsibility

\begin{tabular}{lcc}
\hline Priority Areas for CSR & Yes & No \\
\hline Education & $76.54 \%$ & $23.46 \%$ \\
Health and Sanitation & $69.14 \%$ & $30.86 \%$ \\
Swachh Bharat & $49.38 \%$ & $50.62 \%$ \\
Rural Development & $61.73 \%$ & $38.27 \%$ \\
Skills Development for Employment Opportunities & $46.91 \%$ & $53.09 \%$ \\
Environment & $67.90 \%$ & $32.10 \%$ \\
\hline
\end{tabular}

In India CSR has been mandated as per Companies Act, 2013 for those companies falling into the turnover, profit, and net worth threshold prescribed in the act. The Companies Act, 2013 also suggested activities that may be included by companies in their CSR policies in Schedule VII. However, several questions were presented before respondents to know the priority areas where there is a need of development and CSR amount should be spent by companies. According to majority of respondents there is a need of development in education, environment, health \& sanitation, and rural developments and CSR amount should be spent in these areas. Surprisingly the Companies Act, 2013 guidelines for including activities in CSR policies and respondents opinion about priority areas of CSR are almost in same direction. This reveals that the activities prescribed in new companies act are result of public survey, need of nation, and critical examination of the issues in present time.

Impact of public perception of CCCSR on companies' access to capital from public issue

Table 7

Model Summary

\begin{tabular}{cccccc}
\hline Model & $\mathrm{R}$ & R Square & $\begin{array}{c}\text { Adjusted R } \\
\text { Square }\end{array}$ & $\begin{array}{c}\text { Std. Error of the } \\
\text { Estimate }\end{array}$ & Durbin-Watson \\
\hline & $.913 \mathrm{c}$ & 0.8337 & $\mathbf{0 . 8 3 3 7}$ & 0.5261 & 2.0467 \\
\hline
\end{tabular}

The above table indicates the adjusted $\mathrm{R}$ square for the model is 0.8337 ; statistically it means more than $83 \%$ of the variance in dependent variable is explained by selected independent variable. In this model the dependent variable is ACPI (Access to Capital from Public Issue) and independent variables are RC_CCCSR (Responsible Company), ESW_ACCCSR (Actions for Environmental and Social Wellbeing), and PWOM_CCCSR (Positive Word-ofMouth). To examine the autocorrelation assumption Durbin-Watson is used. The value of Durbin-Watson is 2.0467 this is very close to 2 this means there is no autocorrelation problem in the model. 
Table 8

ANOVA Analysis

\begin{tabular}{lccccc}
\hline & Sum of Squares & Df & Mean Square & F & Sig. \\
\hline Regression & 106.8598 & 3 & 35.6199 & 128.6884 & 0.000 \\
Residual & 21.3130 & 77 & 0.2768 & & \\
Total & 128.1728 & 80 & & & \\
\hline
\end{tabular}

$\mathrm{H}_{0}$ : The model has no significant predictive capability.

$\mathrm{H}_{1}$ : The model has significant predictive capability.

Though the model explains more than $83 \%$ variance but whether this relationship is significant or not is tested through F-statistics. The p-value for F-statistics is 0.000 which indicates that the model is significant predictive capability and RC_CCCSR, ESW_ACCCSR, and PWOM_CCCSR reveals significant explanation in ACPI.

Table 9

Coefficients and Significance Values in Model

\begin{tabular}{lccccc}
\hline & UCE Beta & SE & SCE Beta & t & Sig. \\
\hline (Constant) & 0.0063 & 0.1897 & & 0.0332 & 0.9736 \\
RC_CCCSR & $\mathbf{0 . 4 4 7 1}$ & 0.0679 & 0.4539 & 6.5878 & $\mathbf{0 . 0 0 0 0}$ \\
ESW_ACCCSR & 0.3022 & 0.0726 & 0.3126 & 4.1640 & $\mathbf{0 . 0 0 0 1}$ \\
PWOM_CCCSR & 0.2648 & 0.0703 & 0.2566 & 3.7681 & $\mathbf{0 . 0 0 0 3}$ \\
\hline
\end{tabular}

$\mathrm{H}_{0}$ : Customers perception of a responsible company has no significant influence on the access to capital from public issues.

$\mathrm{H}_{1}$ : Customers perception of a responsible company has significant influence on the access to capital from public issues.

$\mathrm{H}_{0}$ : Customers perception of environmentally and socially wellbeing company has no significant influence on the access to capital from public issues.

$\mathrm{H}_{1}$ : Customers perception of environmentally and socially wellbeing company has significant influence on the access to capital from public issues.

$\mathrm{H}_{0}$ : Customers positive word of mouth about the company has no significant influence on the access to capital from public issues.

$\mathrm{H}_{1}$ : Customers positive word of mouth about the company has no significant influence on the access to capital from public issues.

The above table presents standardized \& unstandardized co-efficient of independent variable and t-statistics to examine the significance of independent variables co-efficient. The p-value for all three independent variable is less than 0.05 which indicate the values of co-efficient or betas for independent variables are significant. 
Table 10

Correlation and Collinearity Statistics of Model

\begin{tabular}{lccccc}
\hline & \multicolumn{3}{c}{ Correlations } & \multicolumn{2}{c}{ Collinearity Statistics } \\
\hline & Zero-order & Partial & Part & Tolerance & VIF \\
\hline (Constant) & & & & & \\
RC_CCCSR & 0.840433344 & 0.600384 & 0.306140085 & 0.45497726 & 2.197912062 \\
ESW_ACCCSR & 0.818056534 & 0.428712 & 0.193504243 & 0.38315195 & 2.609930625 \\
PWOM_CCCSR & 0.766082054 & 0.394572 & 0.175105338 & 0.46584777 & 2.146623982 \\
\hline
\end{tabular}

The above table presents the correlation and collinearity statistics. The VIF i.e. Variance Inflation Factor for all independent variables is near by 2 that mean there is no significant multi-collinearity between independent variables.

Table 11

ANOVA for Breusch Pagan Test

\begin{tabular}{lccccc}
\hline & Sum of Squares & Df & Mean Square & F & Sig. \\
\hline Regression & 0.4264 & 3.0000 & 0.1421 & 0.7582 & $\mathbf{0 . 5 2 1 0}$ \\
Residual & 14.4361 & 77.0000 & 0.1875 & & \\
Total & 14.8625 & 80.0000 & & & \\
\hline
\end{tabular}

$\mathrm{H}_{0}$ : Homoscedasticity - Error term is same across all values of independent variable.

$\mathrm{H}_{1}$ : $\quad$ Heteroscedasticity - Error term is different across all values of independent variables.

$\mathrm{RS}=\alpha+\beta 1 \mathrm{RC} \_C C C S R+\beta 2 \mathrm{ESW} \_\mathrm{ACCCSR}+\beta 3 \mathrm{PWOM} \_\mathrm{CCCSR}+\mathrm{e}$

RS: Residuals Square 
Figure 1

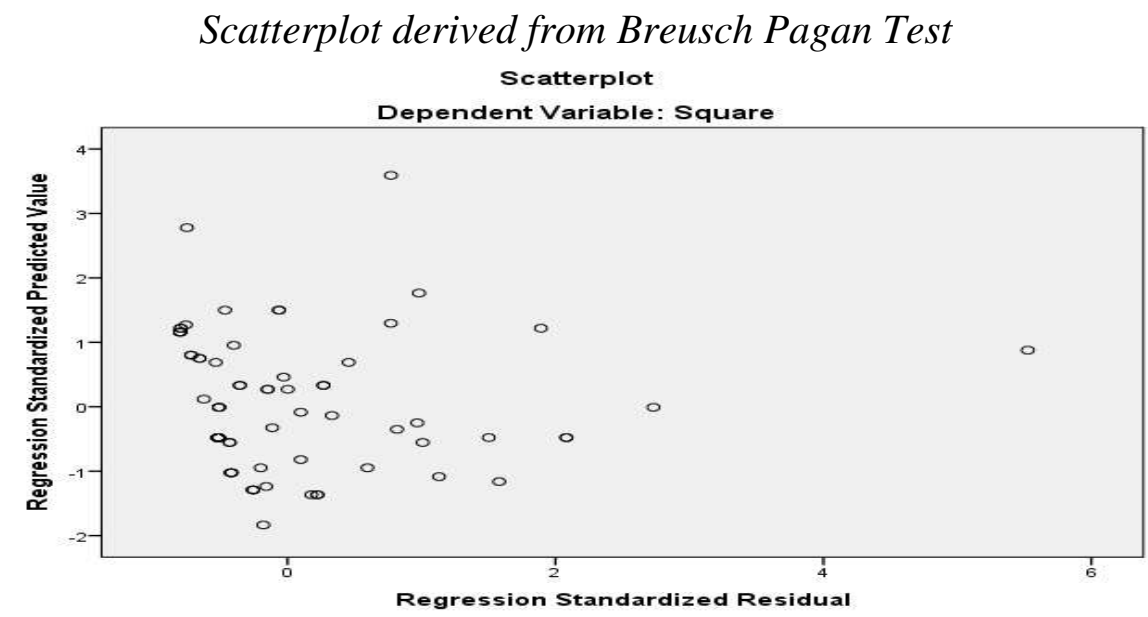

The assumption of homoscedasticity means same variance assumes the situation in which error terms is same across all values of independent variables. To test the assumption Breusch Pagan Test applied on data. The F-statistics shows the p-value greater than 0.05 that means there is homoscedasticity and error term is same across all values of independent variables. The figure also shows a random displacement of scores with no clustering or systematic pattern that is the indication of homoscedasticity.

\section{Regression Model}

$\mathrm{ACPC}=0.0063+0.4471\left(\mathrm{RC} \_C C C S R\right)+0.3022\left(\mathrm{ESW} \_\right.$ACCCSR $)+0.2648\left(\mathrm{PWOM} \_\right.$CCCSR $)+\mathrm{e}$

\section{Conclusion}

This main objective of the study is to identify the people's perception of CSR and their investment preference in companies contributing to CSR. This study found that $85 \%$ of the respondents are aware of CSR and there is no significant association of demographics with the awareness of CSR. This study further found that the majority of respondents believe that the companies contributing to CSR are reputed companies, they satisfy their customers, customers have trust in them, and customers become loyal to these companies. The study further explored that the majority of respondents believe that actions of companies are directed towards environmental and social wellbeing and people prefer products and services offered by CCCSR. The respondents believe that these companies are responsible companies and therefor people spread positive word-of-mouth for these companies but people are not ready to pay higher price for the products and services offered by these companies. Therefor companies should invest in CSR and this investment gives handsome financial and nonfinancial returns in the form of improved company reputation, customer satisfaction, trustworthiness, customer loyalty, investors' confidence etc.

\section{References}

A. Kaifi, B., M. Khanfar, N., O. Noor, A., \& Poluka, L. (2014). International Business Students' Understanding, Perception, and Commitment to Corporate Social Responsibility: A Study Based Upon Gender, Generational Affiliation, and Culture. Business and Management Research, 3(3), 34-42. https://doi.org/10.5430/bmr.v3n3p34 
Abrantes Ferreira, D., Gonçalves Avila, M., \& Dias Faria, M. (2010). Corporate social responsibility and consumers' perception of price. Social Responsibility Journal, 6(2), 208221. https://doi.org/10.1108/17471111011051720

Agudo-Valiente, J. M., Garcés-Ayerbe, C., \& Salvador-Figueras, M. (2017). Corporate social responsibility drivers and barriers according to managers' perception; Evidence from Spanish firms. Sustainability (Switzerland), 9(10). https://doi.org/10.3390/su9101821

Arli, D. I., \& Lasmono, H. K. (2010). Consumers' perception of corporate social responsibility in a developing country. International Journal of Consumer Studies, 34(1), 4651. https://doi.org/10.1111/j.1470-6431.2009.00824.X

Bae, J., \& Kim, S. (2013). The influence of cultural aspects on public perception of the importance of CSR activity and purchase intention in Korea. Asian Journal of Communication, 23(1), 68-85. https://doi.org/10.1080/01292986.2012.725174

Bae, J., \& Kim, S. (2013). The influence of cultural aspects on public perception of the importance of CSR activity and purchase intention in Korea. Asian Journal of Communication, 23(1), 68-85. https://doi.org/10.1080/01292986.2012.725174

Bagire, V. A., Tusiime, I., Nalweyiso, G., \& Kakooza, J. B. (2011). Contextual environment and stakeholder perception of corporate social responsibility practices in uganda. Corporate Social Responsibility and Environmental Management, 18(2), 102-109. https://doi.org/10.1002/csr.252

Castaldo, S., Perrini, F., Misani, N., \& Tencati, A. (2009). The missing link between corporate social responsibility and consumer trust: The case of fair trade products. Journal of Business Ethics, 84(1), 1-15. https://doi.org/10.1007/s10551-008-9669-4

Chu, S. C., \& Lin, J. S. (2013). Consumers' Perception of Corporate Social Responsibility in the United States and China: A Study of Female Cosmetics Consumers. International Journal of Strategic Communication, 7(1), 43-64. https://doi.org/10.1080/1553118X.2012.711401

Dean, D. H. (2003). Consumer perception of corporate donations effects of company reputation for social responsibility and type of donation. Journal of Advertising, 32(4), 91102. https://doi.org/10.1080/00913367.2003.10639149

Dilling, P. (2010). Sustainability Reporting In A Global Context: What Are The Characteristics Of Corporations That Provide High Quality Sustainability Reports - An Empirical Analysis. The International Business \& Economics Research Journal, 9(1), 19-30.

Dilling, P. F. A. (2011). Stakeholder Perception of Corporate. International Journal of Management and Marketing Research, 4(2), 23-34.

Ditlev-Simonsen, C. D. (2015). The Relationship Between Norwegian and Swedish Employees' Perception of Corporate Social Responsibility and Affective Commitment. Business and Society, 54(2), 229-253. https://doi.org/10.1177/0007650312439534 
Elias, R. Z. (2004). An Examination of Business Students' Perception of Corporate Social Responsibilities Before and After Bankruptcies. Journal of Business Ethics, 52(3), 267-281. https://doi.org/10.1023/b:busi.0000037558.74693.d5

Folkes, Valerie S. (1988), "Recent Attribution Research in Consumer Behavior: A Review and New Directions," Journal of Consumer Research, 14 (March), 548-565

Glavas, A., \& Godwin, L. N. (2013). Is the Perception of "Goodness" Good Enough? Exploring the Relationship Between Perceived Corporate Social Responsibility and Employee Organizational Identification. Journal of Business Ethics, 114(1), 15-27. https://doi.org/10.1007/s10551-012-1323-5

Grigore, G. (2009). Corporate social responsibility and reputation. Metalurgia International, 14(11), 95-98.

Huang, C.-C. (2016). Employees' Perception of Corporate Social Responsibility: Corporate Volunteer and Organizational Commitment. International Business Research, 9(9), 142. https://doi.org/10.5539/ibr.v9n9p142

Ingham B. (2006), CSR: A wolf in sheep's skin. Journal of Public Affairs 6: 283-285. DOI $10.1002 / \mathrm{pa}$

Kelly, H. H. (1971), Attribution in Social Interaction, New York: General Learning.

Kim, Y. S., \& Choi, Y. (2012). College Students' Perception of Philip Morris's TobaccoRelated Smoking Prevention and Tobacco-Unrelated Social Responsibility. Journal of Public Relations Research, 24(2), 184-199. https://doi.org/10.1080/1062726X.2012.626138

Lachman, R. and R. A. Wolfe: 1997, 'The Interface of Organizational Effectiveness and Corporate Social Performance', Business \& Society 36, 194-214.

Lee, S., \& Heo, C. Y. (2009). Corporate social responsibility and customer satisfaction among US publicly traded hotels and restaurants. International Journal of Hospitality Management, 28(4), 635-637. https://doi.org/10.1016/j.ijhm.2009.02.007

McWilliams, A., \& Siegel, D. (2001). Corporate social responsibility: A theory of the firm perspective. Academy of Management Review, 26(1), 117-127.

Menu, J. (2020). Perception of Corporate Customer Behaviour in China. 1-11.

Nguyen, M., \& Truong, M. (2016). The Effect of Culture on Enterprise's Perception of Corporate Social Responsibility: The Case of Vietnam. Procedia CIRP, 40, 680-686. https://doi.org/10.1016/j.procir.2016.01.154

Paper, C. (2015). Interaction between Socially Responsible Investment and Macroeconomic variables in South Africa CENTURY: VISUALIZING AND DEVELOPING (Issue August). https://doi.org/10.13140/RG.2.1.2645.6806

Rim and Dong (2018) The paper presents evidence that publics' perception of CSR differ significantly across the three countries. 
Rim, H., \& Dong, C. (2018). Trust and distrust in society and public perception of CSR: A cross-cultural study. Social Responsibility Journal, 14(1), 1-19. https://doi.org/10.1108/SRJ01-2017-0016

Rivera, J. J., Bigne, E., \& Curras-Perez, R. (2016). Efectos de la responsabilidad social corporativa sobre la satisfacción del consumidor con la marca. Spanish Journal of Marketing - ESIC, 20(2), 104-114. https://doi.org/10.1016/j.sjme.2016.06.002

Rodriguez, F.J.G., Cruz, Y.D.M.A., 2007. Relation between social-environmental responsibility and performance in hotel firms. International Journal of Hospitality Management 26 (4), 824-839.

Sharma, P. (2018). A Futuristic Approach towards Cloud Accounting. International Journal of Science and Research, 8(4), 17-25. https://doi.org/10.21275/ART20196629

Sharma, P., \& Raghavi Chakravarthy, N. C. (2020). Knock of advertisement in digital social interaction: Informative or intrusion for social media users. International Journal of Scientific and Technology Research, 9(1).

Shergill, S. S. (2012). Consumers Perception towards the Corporate Social Responsibility : A Case Study of India. 4(4), 47-57.

Sherif, Muzafer, and Carl I. Hovland (1961), Social Judgment: Assimilation and Contrast Effects in Communication and Attitude Change, New Haven: Yale University Press.

Smith, N. (1996), "Ethics and the typology of customer value", Advances in ConsumerResearch, Vol. 23, pp. 148-53.

Strahilevitz, M. (1999), "The effects of product type and donation magnitude on willingness to pay more for a charity-linked brand", Journal of Consumer Psychology, Vol. 8 No. 3, pp. $241-51$

Vahdati, H., Mousavi, N., \& Tajik, Z. M. (2015). The Study of Consumer Perception on Corporate Social Responsibility towards Consumers Attitude and Purchase Behavior. Asian Economic and Financial Review, 531-845. https://doi.org/10.18488/journal.aefr/2015.5.5/102.5.831.845

Varadarajan, P. Rajan, and Anil Menon (1988), "Cause-Related Marketing: A Coalignment of Marketing Strategy and Corporate Philanthropy," Journal of Marketing, 52 (July), 58-74.

Wong, A., Long, F., \& Elankumaran, S. (2010). Csr.216.Pdf. 310(September 2009), 299310 .

Wu, S.-I., \& Wang, W.-H. (2014). Impact of CSR Perception on Brand Image, Brand Attitude and Buying Willingness: A Study of a Global Café. International Journal of Marketing Studies, 6(6), 43-56. https://doi.org/10.5539/ijms.v6n6p43

Zheng, D. (2010). The Impact of Employees ' Perception of Corporate Social Responsibility on Job Attitudes and Behaviors : A Study in China. Management. 
Zhu, Q., Hang, Y., Liu, J., \& Lai, K. hung. (2014). How is employee perception of organizational efforts in corporate social responsibility related to their satisfaction and loyalty towards developing harmonious society in Chinese enterprises? Corporate Social Responsibility and Environmental Management, 21(1), 28-40. https://doi.org/10.1002/csr.1302 